\title{
SISTEM PENDUKUNG KEPUTUSAN PENERIMA BEASISWA DENGAN METODE TECHNIQUE FOR ORDER PREFERENCE BY SIMILARITY TO IDEAL SOLUTION DI UNIVERSITAS SAM RATULANGI MANADO
}

\author{
Kelvin Wijaya $^{1)}$, Hans Wowor $^{2)}$, Virginia Tulenan ${ }^{3)}$ \\ ${ }^{1,2,3}$ Program Studi Teknik Informatika, Fakultas Teknik, Universitas Sam Ratulangi \\ Jl. Kampus UNSRAT Bahu, Manado, 95115 \\ Telp : (0431) 852959, Fax : (0431) 823705 \\ E-mail : kelvin.hwijaya@gmail.com ${ }^{1)}$, hanswowor@ unsrat.ac.id $^{2)}$, \\ virginia.tulenan@unsrat.ac.id ${ }^{3)}$
}

\begin{abstract}
Abstrak
Penelitian yang berjudul "Sistem Pendukung Keputusan Penerima Beasiswa Dengan Metode Technique for Order Preference by Similarity to Ideal Solution di Universitas Sam Ratulangi Manado” ini bertujuan untuk menghasilkan Sistem Pendukung Keputusan yang objektif dan sistematis dalam menentukan penerima beasiswa dengan kualifikasi terbaik.

Metode yang digunakan sebagai tahapan penelitian ini adalah metode Rapid Application Development $(R A D)$ yang merupakan metode rancang bangun perangkat lunak yang menekankan pada daur pengembangan yang singkat. Data yang dijadikan sebagai acuan persyaratan kebutuhan sistem yang dibangun didapatkan dari wawancara terhadap kepala sub bagian kemahasiswaan dan alumni fakultas teknik. Dari data hasil wawancara tersebut didapatkan masalah kurangnya objektifitas dan transparansi informasi dalam proses penentuan penerima beasiswa yaitu belum adanya sebuah standar atau sistem yang digunakan dalam penentuan penerima beasiswa dan hanya menggunakan cara pemilihan manual sehingga penerima beasiswa ditentukan secara subyektif.

Dengan latar belakang tersebut, maka diperlukan Sistem Pendukung Keputusan yang dapat menjadi penunjang bagi proses penentuan penerima beasiswa.
\end{abstract}

Kata kunci: Sistem Pendukung Keputusan, Rapid Application Development (RAD), Beasiswa

\section{PENDAHULUAN}

Dalam penyerahan beasiswa, hal - hal yang harus dipertimbangkan antara lain : kapasitas penerima, pemenuhan persyaratan berupa berkas, kemampuan ekonomi serta kompetensi akademik sesuai dengan ketentuan masing-masing program beasiswa. Universitas Sam Ratulangi merupakan salah satu lembaga pendidikan tinggi penyalur beasiswa bagi mahasiswanya dan saat ini belum ada penerapan metode yang sistematis dan objektif dalam pemilihan penerima beasiswa, sehingga untuk menghindari unsur subjektif dalam pemilihan penerima beasiswa,dibutuhkan sebuah sistem pendukung keputusan dengan proses yang objektif dan sistematis sehingga penerima beasiswa yang ditentukan tepat sasaran dan merupakan kandidat dengan kualifikasi terbaik.

\section{LANDASAN TEORI}

2.1 Studi Literatur / Tinjauan Pustaka

Penelitian ini mengadopsi dari beberapa penelitian sebelumnya:

\begin{tabular}{|c|c|c|c|c|}
\hline $\begin{array}{c}\text { Nama } \\
\text { Peneliti }\end{array}$ & Judul Penelitian & Hasil Penelitian & Persamaan & Perbedaan \\
\hline $\begin{array}{l}\text { Pebriyanto } \\
(2011)\end{array}$ & $\begin{array}{l}\text { Sistem Informasi } \\
\text { Penjualan Berbasis Web } \\
\text { dengan metodologi } \\
\text { RAD (Studi Kasus : PT. } \\
\text { Simtex Mechatronic } \\
\text { Indojaya) }\end{array}$ & $\begin{array}{l}\text { Pendekatan RAD } \\
\text { menghasilkan proses } \\
\text { rancang bangun yang cepat } \\
\text { dan akurat melalui } \\
\text { keterlibatan ekstensif } \\
\text { pengguna dalam konstruksi. }\end{array}$ & $\begin{array}{l}\text { Menggunakan } \\
\text { metodologi } \\
\text { RAD dalam } \\
\text { rancang } \\
\text { bangun } \\
\text { sistem. }\end{array}$ & $\begin{array}{l}\text { Jenis sistem } \\
\text { informasi yang } \\
\text { akan dibangun } \\
\text { adalah sistem } \\
\text { pendukung } \\
\text { keputusan }\end{array}$ \\
\hline
\end{tabular}




\begin{tabular}{|c|c|c|c|c|}
\hline $\begin{array}{l}\text { Nama } \\
\text { Peneliti }\end{array}$ & Judul Penelitian & $\begin{array}{c}\text { Hasil } \\
\text { Penelitian }\end{array}$ & Persamaan & Perbedaan \\
\hline $\begin{array}{l}\text { Wibowo } \\
\text { (2012) }\end{array}$ & $\begin{array}{l}\text { Sistem Pendukung } \\
\text { Keputusan } \\
\text { Penerimaan Asisten } \\
\text { Dosen pada Fakultas } \\
\text { Teknologi Informasi } \\
\text { UKSW }^{[2]}\end{array}$ & $\begin{array}{l}\text { metode TOPSIS } \\
\text { dapat berjalan } \\
\text { dengan baik } \\
\text { untuk } \\
\text { memberikan } \\
\text { hasil } \\
\text { perankingan } \\
\text { calon asisten } \\
\text { dan dapat } \\
\text { membantu } \\
\text { dosen dalam } \\
\text { proses } \\
\text { penerimaan } \\
\text { asisten. }\end{array}$ & $\begin{array}{l}\text { 1) Penggunaan } \\
\text { Metode TOPSIS } \\
\text { dalam memilih } \\
\text { alternatif pilihan } \\
\text { 2) Sistem Pendukung } \\
\text { Keputusan diproses } \\
\text { menggunakan } \\
\text { aplikasi. }\end{array}$ & $\begin{array}{l}\text { 1) Objek penelitian } \\
\text { adalah seleksi } \\
\text { penerima beasiswa di } \\
\text { universitas Sam } \\
\text { Ratulangi Manado } \\
\text { 2) Jumlah, jenis,dan } \\
\text { urgensi kriteria dapat } \\
\text { secara fleksibel } \\
\text { dimodifikasi. } \\
\text { 3) Aplikasi hanya } \\
\text { menghasilkan } \\
\text { alternatif penerima } \\
\text { beasiswa terbaik } \\
\text { berdasarkan metode } \\
\text { TOPSIS. } \\
\text { Pengambilan } \\
\text { keputusan tetap } \\
\text { dilakukan oleh pihak } \\
\text { universitas }\end{array}$ \\
\hline
\end{tabular}

Tabel 1. Studi Literatur

\subsection{Sistem Pendukung Keputusan}

Turban (1995) mendefinisikan DSS dengan lebih spesifik sebagai "sebuah sistem informasi berbasis komputer yang interaktif, fleksibel, dan dapat diadaptasikan, dikembangkan secara khusus untuk mendukung solusi masalah manajemen yang tidak terstruktur untuk peningkatan pengambilan keputusan yang lebih baik. DSS dapat mengutilisasi data, menyediakan interface yang mudah digunakan, dan memungkinkan si pembuat keputusan untuk memberi wawasannya sendiri." ${ }^{[3]}$

Sprague dan Carlson mendefinisikan DSS dengan cukup baik, yakni sebagai sistem yang memiliki lima karakteristik utama ${ }^{[4]}$ : Sistem yang berbasis komputer, Dipergunakan untuk membantu para pengambil keputusan, Untuk memecahkan masalah-masalah rumit yang "mustahil" dilakukan dengan kalkulasi manual, Melalui cara simulasi yang interaktif, Dimana data dan model analisis sebagai komponen utama.

Sehingga dari definisi - definisi diatas, penulis dapat menyimpulkan bahwa Sistem Pendukung Keputusan merupakan Sistem berbasis komputer interaktif dimana data dan model analisis merupakan komponen utama yang digunakan oleh para pengambil keputusan untuk memecahkan masalah - masalah tidak terstruktur.

\subsection{Metode Technique for Order Preference by Similarity to Ideal Solution (TOPSIS).}

TOPSIS adalah salah satu metode pengambilan keputusan multikriteria. Pertama kali diperkenalkan oleh Yoon dan Hwang (1981) ${ }^{[5]}$. TOPSIS menggunakan prinsip bahwa alternatif terpilih harus mempunyai jarak terdekat dari solusi ideal positif dan terjauh dari solusi ideal negatif dari sudut pandang geometris dengan menggunakan jarak Euclidean untuk menentukan kedekatan relatif dari suatu alternatif dengan solusi optimal.

TOPSIS membutuhkan ranking kinerja setiap alternatif Ai pada setiap kriteria $\mathrm{Cj}$ yang ternormalisasi yaitu :

$$
r_{i j}=\frac{x_{i j}}{\sqrt{\sum_{i=1}^{m} x_{i j}^{2}}} \text { dengan } \mathrm{i}=1,2, \ldots . \mathrm{m} \text {; dan } \mathrm{j}=1,2, \ldots \ldots . \mathrm{n} \text {; }
$$

Kemudian, solusi ideal positif A+ dan solusi ideal negatif A- dapat ditentukan berdasarkan ranking bobot ternormalisasi (yij) sebagai berikut :

$$
\begin{array}{rlrl}
y_{i j}=w_{i} r_{i j} & \text { Dimana } y^{+} j & =\max y_{i j} \text { jika } \mathrm{j} \text { adalah atribut nilai. } \\
A^{+}=\left(y^{+} 1, y^{+} 2, \ldots, y^{+} n\right) ; & & =\min y_{i j} \text { jika } \mathrm{j} \text { adalah atribut biaya. } \\
A^{-}=\left(y^{-} 1, y^{-} 2, \ldots, y^{-} n\right) ; & \text { Dimana } y^{-} j & =\max y_{i j} \text { jika } \mathrm{j} \text { adalah atribut biaya. } \\
& =\min y_{i j} \text { jika } \mathrm{j} \text { adalah atribut nilai }
\end{array}
$$

Setelah itu, penghitungan $\mathrm{Si}^{+}$sebagai jarak alternatif dari solusi ideal didefinisikan sebagai :

$S_{i^{+}}=\sqrt{\sum_{j=1}^{n}\left(y_{i j}-y^{+}{ }_{j}\right)}$ dengan $\mathrm{i}=1,2,3 \ldots \mathrm{m}$

Dan jarak terhadap solusi negatif-ideal didefinisikan sebagai $\mathrm{Si}^{-}$:

$S_{i^{-}}=\sqrt{\sum_{j=1}^{n}\left(y_{i j}-y_{j}^{-}\right)^{2}}$ dengan $=1,2,3 \ldots \mathrm{m}$ 
Sehingga, perangkingan alternatif dapat ditentukan untuk menemukan alternatif terbaik berdasarkan kedekatan relatifnya terhadap solusi ideal $\left(\mathrm{C}_{\mathrm{i}}^{*}\right)$ yang didefinisikan sebagai berikut :

$$
C_{i^{*}}=\frac{s_{i^{-}}}{s_{i^{+}}+S_{i^{-}}} \text {dengan } \mathrm{I}=1,2,3 \ldots \mathrm{m}
$$

\subsection{Rapid Application Development (RAD)}

Menurut Kendall (2010), RAD adalah suatu pendekatan berorientasi objek terhadap pengembangan sistem yang mencakup suatu metode pengembangan serta perangkat-perangkat lunak. Terdapat tiga fase dalam RAD yang melibatkan penganalisis dan pengguna dalam tahap penilaian, perancangan, dan penerapan ${ }^{[6]}$.

Adapun ketiga fase tersebut adalah requirements planning, RAD design workshop, dan implementation. Sesuai dengan metodologi RAD menurut Kendall (2010), berikut ini adalah tahapan pengembangan aplikasi.

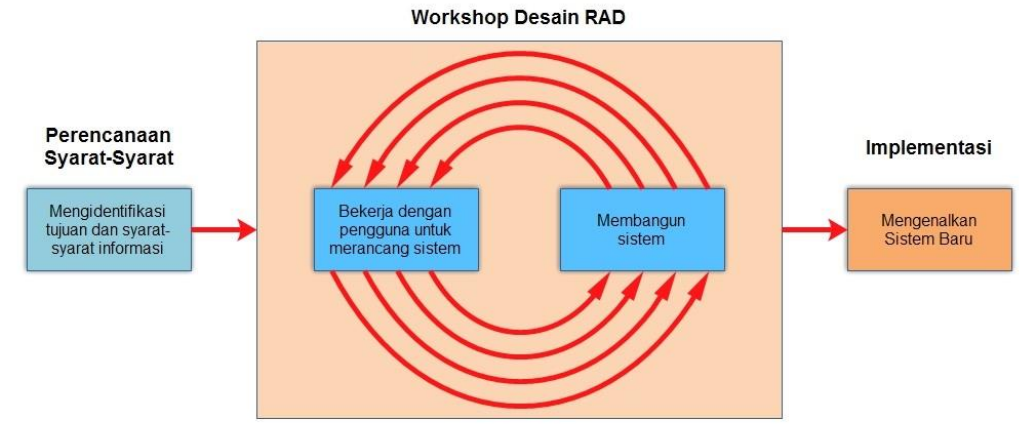

Gambar 1. Tahapan pengembangan dengan metodologi RAD

Tahapan RAD terdiri dari 3 fase, yaitu :

1. Requirements Planning (Perencanaan Persyaratan), yaitu:

a. Pengguna dan analis bertemu untuk mengidentifikasi tujuan dari aplikasi atau sistem.

b. Berorientasi pada pemecahan masalah bisnis.

2. RAD Design Workshop, yaitu:

a. Fase desain dan menyempurnakan.

b. Gunakan kelompok pendukung keputusan sistem untuk membantu pengguna setuju pada desain.

c. Programmer dan analis membangun dan menunjukkan tampilan visual desain dan alur kerja pengguna.

d. Pengguna menanggapi prototipe kerja aktual.

e. Analis menyempurnakan modul dirancang berdasarkan tanggapan pengguna.

3. Implementation (Penerapan), yaitu:

a. Sebagai sistem yang baru dibangun, sistem baru atau parsial diuji dan diperkenalkan kepada organisasi.

b. Ketika membuat sistem baru, tidak perlu untuk menjalankan sistem yang lama secara parallel.

\section{METODOLOGI PENELITIAN}

Sesuai dengan Gambar 2 metodologi penelitian ini menggunakan pendekatan Rapid Application Development (RAD) sehingga fase penelitian yang dilakukan adalah sebagai berikut:

Metodologi RAD, terdiri dari 3 tahap yang terstruktur dan saling bergantung disetiap tahap, yaitu Tahap analisis persyaratan, Tahap RAD Design Workshop (Pemodelan), dan Tahap Konstruksi.

\subsection{Analisis Persyaratan}

- Tujuan : mengidentifikasi kebutuhan, batasan dan objektifitas dari sistem yang akan dibangun ,dengan cara mengumpulkan data dari stakeholder.

- Aktivitas yang dilakukan : Wawancara dengan Kasubag Kemahasiswaan dan Alumni yang menangani informasi dan berkas beasiswa untuk mahasiswa.

- Hasil yang didapatkan: Spesifikasi kebutuhan sistem, program beasiswa serta persyaratan dan urgensinya.

\subsection{RAD Design Workshop (Pemodelan)}

- Tujuan : merancang semua kegiatan dalam arsitektur sistem secara keseluruhan dengan melibatkan identifikasi dan deskripsi abstraksi sistem perangkat lunak yang mendasar dan hubungan-hubungannya

- Aktivitas yang dilakukan: Identifikasi pelaku bisnis, analisis proses \& kinerja sistem, mengidentifikasi struktur objek dan relasinya, Pemodelan interaksi obyek \& behavior, dan mendesain Antarmuka

- Hasil yang didapatkan: Pemodelan Software, Rancangan Basis Data dan Desain Antarmuka Yang dapat dilihat pada gambar 3-5. 

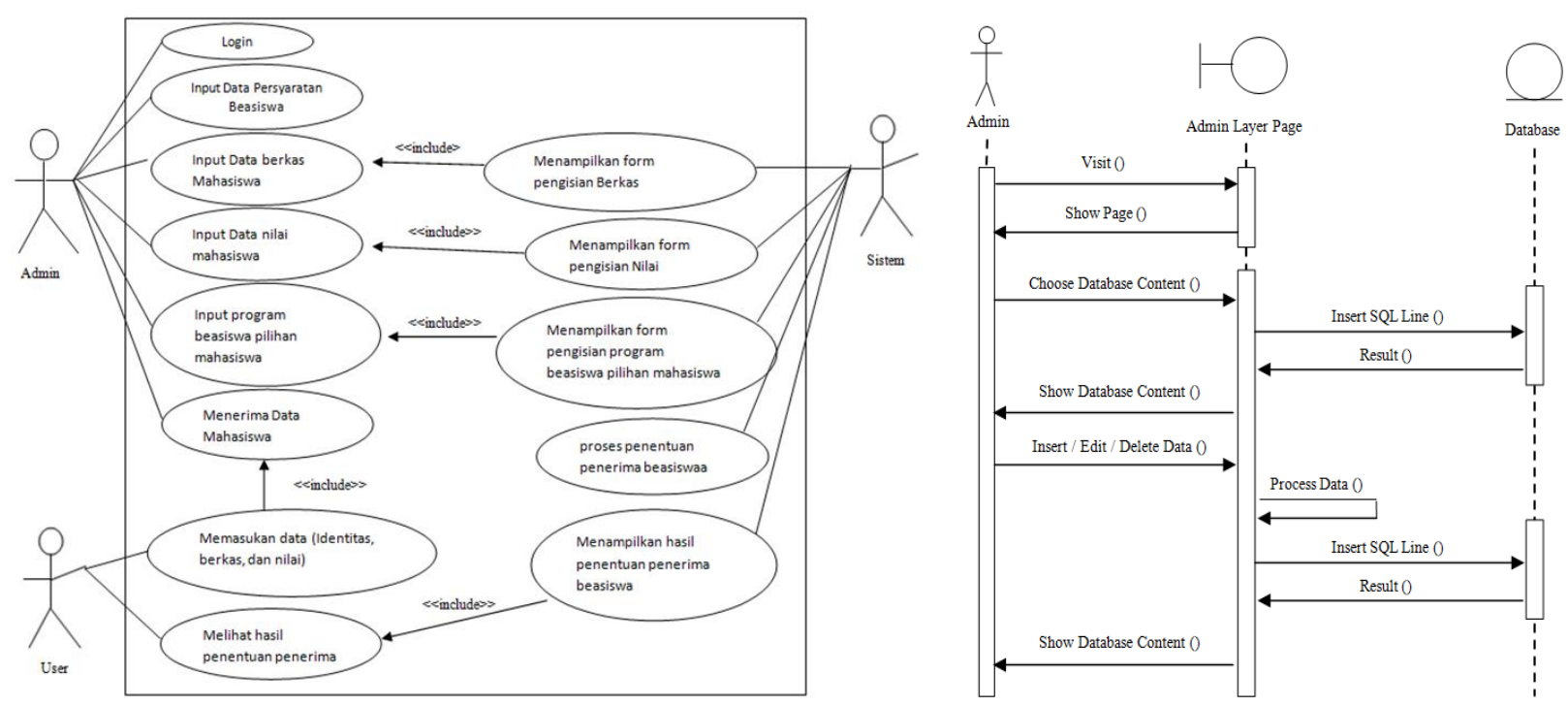

Gambar 2. Use Case dan Sequence Diagram Sistem Pendukung Keputusan Penerima Beasiswa

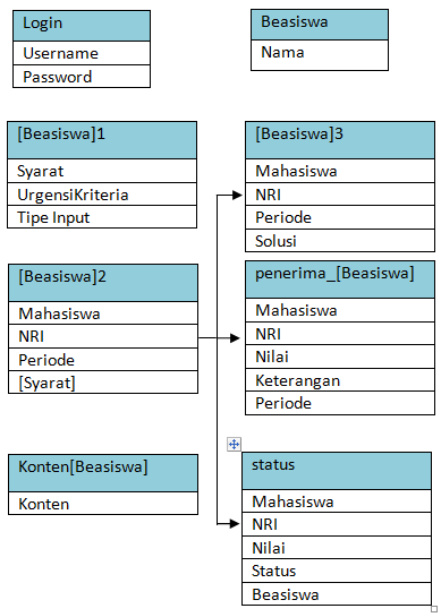

Gambar 3. Skema Tabel Database
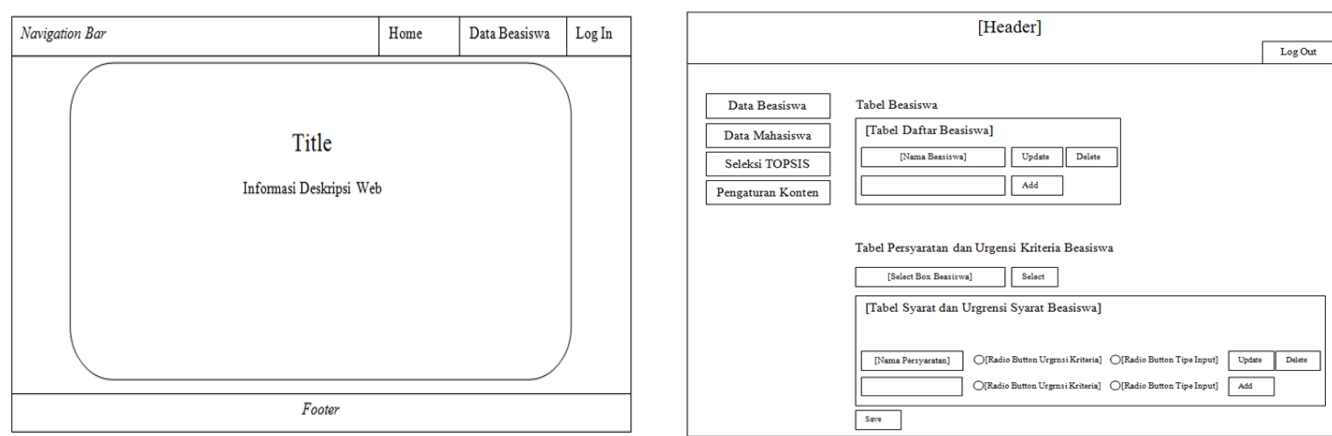

Gambar 4. Desain antarmuka homepage dan halaman admin

\subsection{Implementasi}

- Tujuan : konstruksi sistem dan penerapan metode yang diaptasikan dengan proses seleksi dalam pemrograman terhadap hasil analisa kebutuhan sistem dan akan dijelaskan dalam tahap Implementasi Basis Data dan Coding Program .

- Aktivitas yang dilakukan : Menentukan lingkungan implementasi, Implementasi Basis Data, Pemrograman, antarmuka,dan Pengujian.

- Hasil yang didapatkan: Kode Sumber Program dan hasil pengujian. 


\section{PEMBAHASAN}

Pada bagian pembahasan, penulis akan membahas hasil perancangan dan pengujian sistem yang telah dilakukan pada tahap Implementasi

\subsection{Tahap Implementasi Perancangan Sistem}

Hasil proses konstruksi berdasarkan perancangan sistem pendukung keputusan telah sesuai denganhasil analisa requirement yang dilakukan. User dapat mengakses informasi mengenai beasiswa,penerima serta nilainya yang ada pada navigation bar data beasiswa.

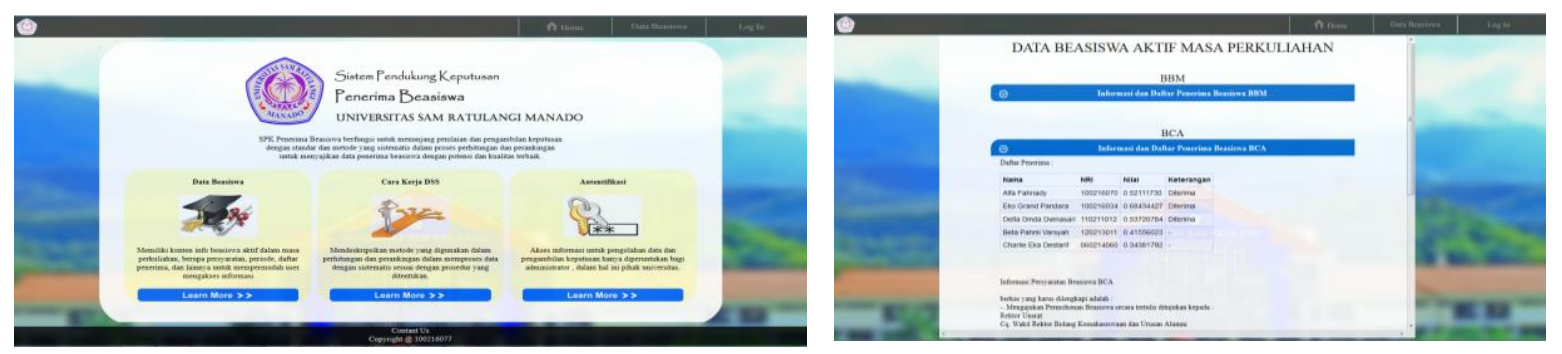

Gambar 5. Homepage dan Halaman Data Beasiswa

Admin dapat mengelola data beasiswa dan mahasiswa dengan fleksibel setelah login seperti yang dapat dilihat pada gambar 7 .

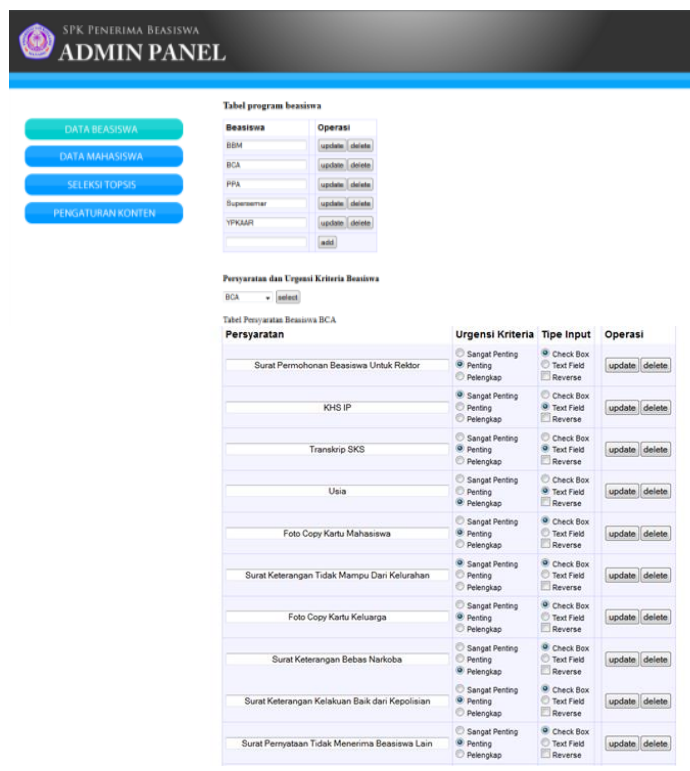

Gambar 6. Halaman Data Beasiswa Admin

Setelah data beasiswa dan urgensinya diinput,admin dapat menginput data mahasiswa, kelengkapan berkas, dan nilainya di $t a b$ data mahasiswa, yang kemudian diproses dengan metode TOPSIS di tab seleksi topsis. Perbandingan perhitungan manual metode TOPSIS dan perhitungan dengan sistem pendukung keputusan penerima beasiswa metode TOPSIS dilakukan dengan input yang sama terhadap persyaratan BBM sebagai berikut: 1.fc Kartu Mahasiswa,2.Kartu Rencana Studi,3.Piagam atau bukti prestasi lainnya,4.Surat pernyataan tidak menerima beasiswa lain, 5.Surat rekomendasi dari pimpinan fakultas,6.fc Kartu Keluarga,7.Surat Keterangan Tidak Mampu dari Kelurahan, dan 8.IPK.dengan jumlah penerima 2 orang dengan nilai tertinggi. Hasil input dan perhitungan metode TOPSIS manual dan melalui sistem dapat dilihat pada gambar 8 dan 9 .

\begin{tabular}{|c|c|c|c|c|c|c|c|c|c|}
\hline No & Calon & 1 & 2 & 3 & 4 & 5 & 6 & 7 & 8 \\
\hline 1 & Agung Pratomo & $\sqrt{ }$ & $\sqrt{ }$ & $\sqrt{ }$ & $\sqrt{ }$ & $\sqrt{ }$ & $\sqrt{ }$ & 3 \\
\hline 2 & Budi Darmawan & $\sqrt{ }$ & $\sqrt{ }$ & $\sqrt{ }$ & $\sqrt{ }$ & $\sqrt{ }$ & $\sqrt{ }$ & 2.95 \\
\hline 3 & Cici Meriyani & $\sqrt{ }$ & $\sqrt{ }$ & $\sqrt{ }$ & $\sqrt{ }$ & $\sqrt{ }$ & 3.2 \\
\hline 4 & Beta Pahmi Varsyah & $\sqrt{ }$ & & & & $\sqrt{ }$ & $\sqrt{ }$ & 2.9 \\
\hline 5 & Enda Jayatri & $\sqrt{ }$ & $\sqrt{ }$ & $\sqrt{ }$ & $\sqrt{ }$ & $\sqrt{ }$ & $\sqrt{ }$ & 3.3 \\
\hline
\end{tabular}

Perankingan

Enda Jayatri : 1 (Diterima)

Budi Darmawan :0.0899 (Diterima)

Agung Pratomo : 0.0837

Cici Meriyani : 0.0826

Beta Pahmi Varsyah : 0

Gambar 7. Input dan Hasil Perhitungan Manual Metode TOPSIS 


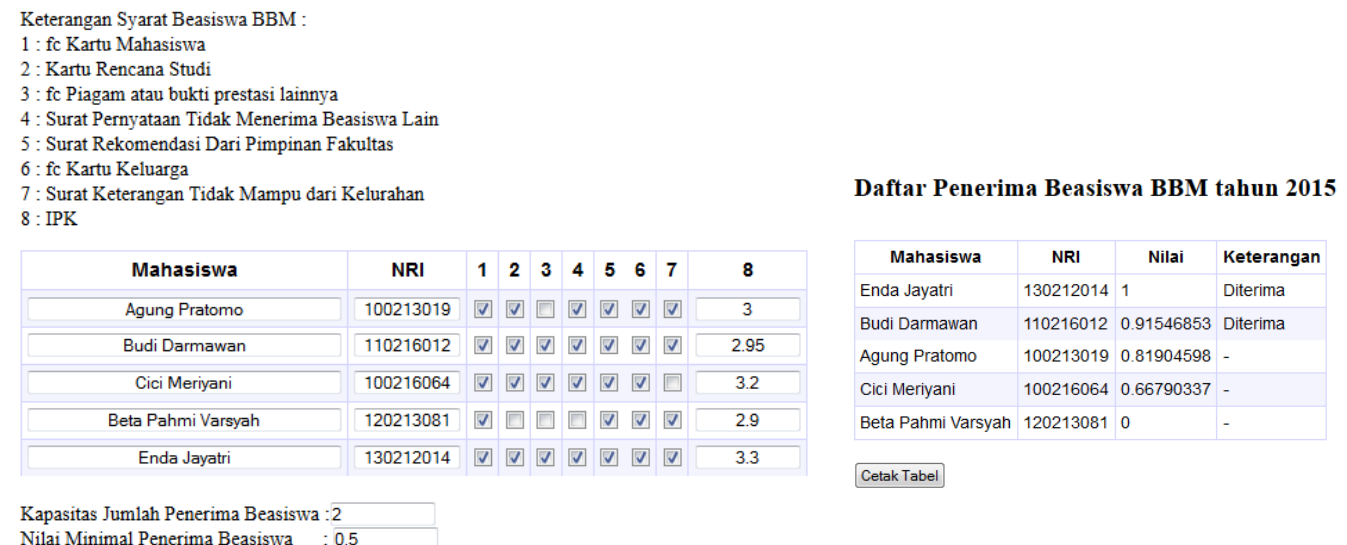

\section{Gambar 8. Input dan Hasil Perhitungan TOPSIS Menggunakan Sistem}

Seperti yang dapat dilihat di gambar 8 dan 9, hasil perhitungan manual dan dengan sistem pendukung keputusan metode TOPSIS mendapatkan hasil penerima beasiswa yang sama dengan perhitungan yang 1 akurat.

\subsection{Pengujian Sstem}

Tujuan dari tahap terakhir ini yaitu menguji sistem dan mereview sistem. Hasil yang didapatkan adalah sebagai berikut :

\begin{tabular}{|c|l|l|l|l|}
\hline $\begin{array}{c}\text { Testing } \\
\text { Halaman }\end{array}$ & \multicolumn{1}{|c|}{$\begin{array}{c}\text { Hasil Yang } \\
\text { Diharapkan }\end{array}$} & $\begin{array}{c}\text { Hasil Yang } \\
\text { Didapatkan }\end{array}$ & Keterangan & \multicolumn{1}{c|}{ Solusi } \\
\hline Seleksi Topsis & $\begin{array}{l}\text { Sistem dapat } \\
\text { memproses data } \\
\text { dengan semua } \\
\text { input yang } \\
\text { bernilai sama }\end{array}$ & $\begin{array}{l}\text { Terjadi error } \\
\text { dalam proses } \\
\text { TOPSIS akibat } \\
\text { pembagian } \\
\text { dengan 0 (jarak } \\
\text { relatif nilai). }\end{array}$ & Bermasalah & $\begin{array}{l}\text { Menambah kondisi } \\
\text { pencegahan pembagian } \\
\text { 0 dan menambah } \\
\text { variabel waktu sebagai } \\
\text { prioritas jika semua } \\
\text { nilai input sama }\end{array}$ \\
\hline
\end{tabular}

Tabel 2. Pengujian Sistem

\section{PENUTUP}

\subsection{Kesimpulan}

Kesimpulan yang didapat:

a) Sistem pendukung keputusan penerima beasiswa dengan metode TOPSIS dapat secara objektif membantu pengambilan keputusan penerima beasiswa berdasarkan kriteria - kriteria dan urgensinya yang dapat dengan dinamis dimodifikasi (tambah,hapus,perbarui) berdasarkan kebutuhan dan menggunakan metode yang sistematis untuk menentukan penerima beasiswa .

b) Berdasarkan hasil pengujian fungsi, Sistem pendukung keputusan penerima beasiswa dengan metode TOPSIS menunjukan fungsi proses yang objektif, sistematis dan fleksibel untuk setiap mahasiswa dan program beasiswa, sehingga memberi hasil yang optimal dalam pemilihan penerima beasiswa.

\subsection{Saran}

Saran pengembangan sistem kedepannya:

a) Sistem pendukung keputusan penerima beasiswa dengan metode TOPSIS ini menjadi bagian dari proses penentuan keputusan penerima beasiswa yang lebih objektif dan transparan.

b) Penelitian terhadap pengembangan dan implementasi Sistem pendukung keputusan penerima beasiswa dengan metode TOPSIS disarankan untuk dilanjutkan dengan aspek penelitian lainnya dalam hal kajian yang lebih luas, seperti pengaruh,efektivitas dan keakuratan metode dan hasil implementasinya

\section{DAFTAR RUJUKAN}

[1] Pebriyanto. "Sistem Informasi Penjualan Berbasis Web dengan metodologi RAD (Studi Kasus : PT.

Simtex Mechatronic Indojaya) ", (2011)

[2] Wibowo 2012. "Sistem Pendukung Keputusan Penerimaan Asisten Dosen pada Fakultas Teknologi Informasi UKSW", (2011)

[3] Turban,E."Decision support and expert systems:management support systems”, (1995)

[4] Sprague, R. H. and E. D. Carlson." Building effective decision support systems", (1993).

[5] D. Ozturk and F. Batuk ." Technique For Order Preference By Similarity To Ideal Solution (Topsis) For Spatial Decision Problems",(2011)

[6] Kendall, J.E. \& Kendall, K.E ”Analisis dan Perancangan Sistem. Jakarta: Indeks", (2010) 